DOI: $10.29303 /$ jrpb.v9i2.277

ISSN 2301-8119, e-ISSN 2443-1354

Tersedia online di http://jrpb.unram.ac.id/

\title{
PENGARUH VARIASI WAKTU OZONISASI DAN SUHU PENYIMPANAN TERHADAP KARAKTERISTIK FISIKA, KIMIA, DAN SENSORIS PADA DAGING AYAM BROILER (Gallus domesticus)
}

The Effect of Ozone Exposure Time Variations and Storage Temperature on Physical, Chemical, and Sensory Characteristics in Broiler Chicken (Gallus domesticus) Meat

\author{
Sigit Prabawa, D. K. Ramadhanty Putri, Kawiji, Bara Yudhistira*) \\ Prodi Ilmu Teknologi Pangan, Fakultas Pertanian, Universitas Sebelas Maret \\ Jl. Ir. Sutami, No.36A, Jebres, Surakarta, Indonesia \\ Email*): barayudhistira@staff.uns.ac.id
}

Diterima: Juli 2021

Disetujui: September 2021

\begin{abstract}
Broiler chicken (Gallus domesticus) refers to a type of livestock developed to meet the needs of animal protein. Since it belongs to fresh foods and contains high water content, broiler chicken meat is susceptible to spoilage caused by microbes. Treatment using ozone and storage temperature is able to maintain the quality of chicken meat in terms of physical, chemical, and sensory qualities. This study aimed to determine the effect of ozone treatment and storage temperature on physical, chemical, and sensory properties of broiler chicken meat. The immersion times were 5, 10, and 15 minutes, while the storage temperatures were $10^{\circ} \mathrm{C}$ and $-6^{\circ} \mathrm{C}$. This research was conducted using a Factorial Complete Randomized Design (RALF) and further analysis using Duncan's Multiple Range Test (DMRT). The results obtained indicated that ozone treatment and freezing temperature are effective in reducing the drip loss value and concurrently increasing cooking loss, decreasing the color attribute, reducing the $a_{w}$ value, maintaining the $\mathrm{pH}$ value, maintaining the rate of increase in TBARS and TVB-N, and maintaining the value of consumer preference. The most effective treatment for chicken meat was 15 minutes immersion and $-6^{\circ} \mathrm{C}$ storage temperature that was proven able to maintain drip loss, $a_{w}, p H, T B A R S, T V B-N$, and sensory quality of chicken meat.
\end{abstract}

Keywords: broiler chicken; chicken meat; ozonization; frozen storage; cold storage

\begin{abstract}
ABSTRAK
Ayam broiler (Gallus domesticus) merupakan jenis ternak yang banyak dikembangkan sebagai sumber pemenuhan kebutuhan protein hewani. Namun, karena merupakan bahan segar dan memiliki kandungan air yang tinggi, daging ayam broiler rentan terhadap kebusukan yang disebabkan oleh mikroba. Perlakuan dengan ozon dan suhu penyimpanan mampu mempertahankan kualitas daging ayam ditinjau dari kualitas fisika, kimia, dan sensoris. Penelitian ini bertujuan untuk mengetahui pengaruh perlakuan ozonisasi dan suhu penyimpanan terhadap sifat fisika, kimia, dan sensoris daging ayam broiler. Variasi waktu
\end{abstract}


perendaman, yaitu 5, 10, dan 15 menit, sedangkan untuk variasi penyimpanan yaitu $10^{\circ} \mathrm{C}$ dan $-6^{\circ} \mathrm{C}$. Penelitian ini dilakukan menggunakan Rancangan Acak Lengkap Faktorial (RALF) dan analisis lanjutan menggunakan DMRT. Hasil yang didapatkan adalah perlakuan ozon dan suhu beku efektif dalam mengurangi nilai drip loss namun meningkatkan susut masak, menurunkan atribut warna, mengurangi nilai $a_{w}$, mempertahankan nilai $\mathrm{pH}$, mempertahankan laju kenaikan TBARS dan TVB-N mempertahankan nilai kesukaan konsumen. Perlakuan paling efektif untuk daging ayam yaitu dengan perendaman selama 15 menit dan penyimpanan dengan suhu $-6^{\circ} \mathrm{C}$ mampu mempertahankan drip loss, $a_{w}, \mathrm{pH}$, TBARS, TVB$\mathrm{N}$, dan sensoris dari daging ayam.

Kata kunci: ayam broiler; daging ayam; ozonisasi; penyimpanan beku; penyimpanan dingin

\section{PENDAHULUAN}

\section{Latar Belakang}

Ayam broiler (Gallus domesticus) merupakan jenis ternak yang banyak dikembangkan sebagai sumber pemenuhan kebutuhan protein hewani. Ayam broiler memiliki pertumbuhan yang cepat, hal ini karena ayam broiler merupakan hasil budidaya yang menggunakan teknologi maju, sehingga memiliki sifat ekonomi yang menguntungkan (Pratikno, 2010). Ayam broiler merupakan salah satu sumber protein hewani yang murah dibanding dengan daging yang lain. Keunggulan ayam broiler adalah pertumbuhannya yang sangat cepat, sehingga dapat dijual sebelum usia 5 minggu, dengan bobot rata-rata $1,5 \mathrm{~kg}$. Ayam broiler sangat efisien dalam mengubah pakan menjadi daging (Situmorang, et al., 2013).

Daging ayam broiler adalah bahan makanan mengandung gizi tinggi, memiliki rasa dan aroma yang enak, tekstur yang lunak dan harga yang relatif murah, sehingga disukai hampir semua orang. Komposisi kimia daging ayam terdiri dari protein 18,6\%; lemak 15,06\%; air 65,95\%; dan abu 0,79\% (Suradi, 2006). Bahan pangan asal ternak (daging, telur, susu) serta olahannya mudah rusak dan merupakan media yang sangat baik bagi pertumbuhan mikroba. Jumlah dan jenis mikroba berbahaya pada daging ayam yang dijual di pasar tradisional cukup mengkhawatirkan, terlebih lagi bila pemotongan ayam dilakukan di pasar tradisional (Gustiani, 2009). Perlu adanya perlakuan dimana dapat mempertahankan karakteristik daging ayam yang disimpan salah satunya dengan teknik ozonisasi dan penggunaan suhu yang sesuai untuk penyimpanan daging ayam.

Ozon merupakan senyawa berbentuk gas dengan berat molekul 48 gram terdiri dari tiga atom oksigen, bersifat labil, karena cepat sekali terurai menjadi oksigen normal yang mempunyai dua atom atau $\mathrm{O}_{2}$ dan satu atom oksigen bebas atau $\mathrm{O}$-nesen (On). Ozon memiliki titik didih $-112^{\circ} \mathrm{C}$, sebagian dapat larut dalam air. Dibandingkan dengan kelarutan oksigen, kelarutan ozon 20 kali lebih besar, baunya khas sehingga mudah untuk mendeteksinya meskipun konsentrasinya rendah $(0,01-$ 0,05 ppm) (Rusdi dan Sulasih, 2002). Ozon merupakan senyawa pengoksidasi yang kuat. Sifat reaktif dari ozon disebabkan oleh kemampuan oksidasi dari radikalradikal yang dapat mendekomposisi ozon dalam air, sehingga menghasilkan senyawa intermediant aktif seperti radikal hidroksil dan superoksida (Asgar, et al., 2015).

Mekanisme ozon dalam membunuh mikroba yaitu ozon melakukan penyerangan pada dinding sel mengarah pada perubahan dalam permeabilitas dari sel dan dapat menyebabkan terjadnya lisis pada sel bakteri (Asgar, et al., 2011). Ozon akan bereaksi dengan semua protoplasma sel dengan berperan sebagai oksidator. Ozon akan langsung menyerang lapisan permukaan bakteri, yaitu mengadakan oksidasi sulfidril dari enzim, atau 
mengadakan oksidasi dengan lipoprotein dan lipopolisakarida yang merupakan lapisan paling besar dari bakteri gram negatif. Hal ini akan menyebabkan rusaknya pertahanan permeabilitas sel sehinga akan mengalami lisis (Rusdi \& Sulasih, 2002). Air yang telah mengandung ozon dapat digunakan untuk mencuci buah dan sayur agar steril, tanpa menghilangan warna, aroma, dan tidak mengurai senyawa organik yang terkandung dalam bahan pangan sehingga mampu memperpanjang umur kesegaran (Asgar, et al., 2011).

Penyimpanan dingin pada lemari es merupakan cara yang paling sederhana dan sering digunakan untuk mengawetkan serta memperpanjang masa simpan daging ayam. Pendinginan dapat menghambat pertumbuhan mikroorganisme, karena suhu dingin akan menurunkan energi kinestetik semua molekul dalam sistem, sehingga menurunkan kecepatan reaksi kimia termasuk aktivitas metabolisme sel mikroba.

Daging ayam merupakan media yang baik untuk pertumbuhan mikroorganisme. Hal ini disebabkan karena daging ayam yang mengandung air, kaya nitrogen serta $\mathrm{pH}$ yang baik untuk pertumbuhan mikroorganisme (Jaelani, et al., 2014). Dengan demikian pada penelitian ini dilakukan perlakuan pendahuluan untuk mempertahankan karakteristik daging ayam yang disimpan yaitu dengan memanfaatkan teknologi ozonisasi dan penggunaan suhu penyimpanan yang sesuai. Tujuan dari penelitian ini adalah untuk mengetahui pengaruh variasi waktu ozonisasi dan suhu penyimpanan terhadap sifat fisik (drip loss, susut masak dan warna), kimia $\left(\mathrm{a}_{\mathrm{w}}, \mathrm{pH}\right.$, TBARS, dan TBVN) dan analisa sensori dari ayam broiler. Kombinasi teknologi ozonisasi dan pendinginan diharapakan mampu mempertahankan kualitas daging ayam broiler.

\section{METODE PENELITIAN}

\section{Alat dan Bahan \\ $\underline{\text { Alat }}$}

Alat yang digunakan dibagi menjadi tiga, yaitu alat persiapan, alat perlakuan pengemasan dan pendinginan dan alat analisis. Alat untuk persiapan awal terdiri dari baskom, lap, pisau, talenan, timbangan analitik, bak penampung air, dan generator ozon. Alat untuk pengemasan dan penyimpanan yaitu gunting, wadah $\mathrm{pp}$ thinwall ketebalan $0,4 \mathrm{~mm}$, refrigerator (Polytron SCN233), freezer (SingerCF3403), dan termometer. Alat untuk analisis yaitu neraca analitik (Portable scale SFC SF-400C), termometer, panci, kompor, chromameter (Konica Minolta CR-400), pisau, $a_{w}$ meter (Aqualab Pawkit), pH meter (Nutrontech PH-009-A), gelas beaker (Pyrex), baskom, talenan, gelas ukur (Pyrex), blender (WaringMX1050XTX), labu destilasi (Pyrex), batu didih (Flinn Scientific B0136), set alat destilasi (Pyrex), pipet volume (Pyrex), propipet (Glasfirn pl-pump), water bath (Memmert-WNB 29), spektrofotometer (Shimadzu UV-mini-1240), label, piring kertas, dan borang uji.

\section{Bahan}

Bahan utama yang digunakan untuk analisis yaitu fillet daging bagian dada ayam broiler dengan umur siap potong 35 40 hari dengan berat fillet $1,5-2,0 \mathrm{~kg}$ yang didapat dari supplier ayam Kalilondo, Kota Salatiga, Jawa Tengah. Untuk bahan analisis yaitu plastik wrap ketebalan 10 mikron (Klin Pak), aquades, es batu, $\mathrm{HCl}$ $4 \mathrm{M}$, antifoaming agent, TBA, TCA 5\%, $\mathrm{NaOH}$.

\section{Metode}

Persiapan Sampel

Fillet daging bagian dada ayam broiler segar (Gallus domesticus) dipotong dan dilakukan penimbangan dengan berat masing-masing sampel sekitar $150 \mathrm{~g}$ untuk formulasi perendaman $0,5,10,15$ menit 
dan untuk masing-masing penyimpanan dengan suhu $10^{\circ} \mathrm{C}$ dan $-6^{\circ} \mathrm{C}$ sehingga didapatkan 8 formulasi perlakuan. Seluruh perlakuan dilakukan 3 kali ulangan sampel dan analisa.

\section{Persiapan dan Proses Ozonisasi}

Pengisian air ke dalam bak penampung ozon sebanyak \pm 54 liter. Generator dihidupkan selama 1 jam sebelum dilakukan ozonisasi pada daging ayam broiler. Setelah 1 jam penghidupan generator, sampel dimasukkan ke dalam bak penampung untuk direndam selama 5 , 10, dan 15 menit. Untuk sampel kontrol atau 0 menit tidak perlu dilakukan perendaman. Setelah direndam sampel dikeringkan menggunakan tisu lalu dikemas menggunakan wadah pp thinwall ketebalan 0,4 mm dan dikemas dua lapis menggunakan plastik wrap ketebalan 10 mikron untuk selanjutnya dilakukan penyimpanan pada suhu $10^{\circ} \mathrm{C}$ dan $-6^{\circ} \mathrm{C}$ selama 2 hari. Teknik ozonisasi ini mengacu pada metode dari Novak dan Yuan (2004) dengan melakukan modifikasi dan penyesuaian.

\section{Analisis Fisik}

\section{Drip Loss}

Analisa drip loss mengacu pada Lyu, et al., (2016) sesuai Persamaan 1. Sampel ditimbang sebanyak 150 gram dan diletakkan pada wadah pp thinwall ketebalan $0,4 \mathrm{~mm}$ serta dikemas dua lapis menggunakan plastik wrap. Sampel dilakukan penimbangan baik sebelum dan setelah ozonisasi untuk mendapatkan drip loss pada hari ke-0 dan hari kedua.

$$
\begin{aligned}
& \text { Drip loss }(\%)=\frac{\left(\mathrm{W}_{1}-\mathrm{W}_{2}\right)}{\mathrm{W}_{1}} \times 100 \% \ldots(1) \\
& \text { Keterangan: } \\
& \begin{array}{l}
\mathrm{W}_{1} \quad=\text { berat awal sebelum perlakuan }(\mathrm{g}) \\
\mathrm{W}_{2} \quad=\text { berat sesudah perlakuan dan } \\
\text { penyimpanan }(\mathrm{g})
\end{array}
\end{aligned}
$$

\section{Susut Masak}

Sampel daging ayam dipotong dengan ukuran $4 \times 3 \times 1 \mathrm{~cm}^{3}$ dan kemudian ditimbang serta dimasukkan pada plastik zip-lock. Air dituangkan ke dalam panci, kemudian dipanaskan sampai suhu stabil $80^{\circ} \mathrm{C}$. Selanjutnya daging ayam tersebut dimasukkan ke dalam panci dan sampai suhu bagian tengah daging menjadi $75^{\circ} \mathrm{C}$ dan dibiarkan selama 10 menit. Setelah 10 menit, daging ayam diangkat untuk kemudian didinginkan menggunakan air mengalir sampai mencapai suhu ruang. Daging kemudian dilap menggunakan tisu. Analisa susut masak mengacu pada penelitian Shen, et al., (2019) dengan sedikit modifikasi (Persamaan 2).

Susut masak $(\%)=\frac{\left(\mathrm{M}_{1-}-\mathrm{M}_{2}\right)}{\mathrm{M}_{1}} \times 100 \%$

Keterangan:

$\mathrm{M}_{1}=$ berat awal sebelum perebusan ( $\mathrm{g}$ )

$\mathrm{M}_{2}=$ berat sesudah perebusan $(\mathrm{g})$

\section{$\underline{\text { Warna }}$}

Analisa warna mengacu pada metode Jeong dan Claus (2010). Sampel dipotong kemudian dimasukkan dalam cup plastic dan sekeliling cup ditutup menggunakan karton hitam. Chromameter (Konica Minolta CR-400) ditempelkan pada mulut cup. Tombol on ditekan, selanjutnya hasil pengujian diamati untuk dicatat. Analisa warna mengacu pada sistem CIE dengan skala $L^{*}$ warna $0-100$ adalah putih dan untuk a* nilai positif (+) merupakan warna merah dan nilai negatif (-) merupakan warna hijau sedangkan pada nilai $b^{*}$ nilai positif (+) merupakan warna kuning dan nilai negatif (-) merupakan warna biru.

\section{Analisis Kimia}

$\underline{\text { Aktivitas Air }}$

Daging ayam dipotong kemudian dimasukkan ke dalam cup. Selanjutnya $a_{w}$ meter (pawkit) dipasang pada cup dan diletakkan pada bidang datar. Tombol on ditekan agar alat menyala kemudian tombol on ditekan sekali lagi untuk membaca sampel dan ditunggu sampai angka berhenti. Analisa ini mengacu pada McDermott, et al. (2018). 
$\underline{\mathrm{pH}}$

Analisa $\mathrm{pH}$ mengacu metode Lyu, et al., (2016) dengan sedikit modifikasi. Daging ayam dicincang dan diambil sebanyak $5 \mathrm{~g}$ kemudian dilarutkan dalam aquades $45 \mathrm{ml}$ dan dihomogenisasi selama 1 menit. Larutan dimasukan ke dalam gelas beaker dan dinginkan pada air es hingga suhu $20^{\circ} \mathrm{C}$ kemudian $\mathrm{pH}$ diukur menggunakan $\mathrm{pH}$ meter.

\section{TBARS}

Bahan sebanyak $10 \mathrm{~g}$ ditimbang kemudian dimasukkan ke waring blender dan ditambahkan $50 \mathrm{ml}$ aquades selanjutnya dihancurkan selama 5 menit. Sampel dipindahkan secara kuantitatif ke dalam labu destilasi sambil dicuci dengan $47,5 \mathrm{ml}$ aquades dan ditambahkan $\pm 2,5 \mathrm{~mL}$ $\mathrm{HCl} 4 \mathrm{M}$ sampai $\mathrm{pH}$ menjadi 1,5. Batu didih dan antifoaming agent ditambahkan lalu destilasi dijalankan dengan pemanas tinggi sampai diperoleh $50 \mathrm{~mL}$ destilat selama 10 menit pemanasan. Destilat sebanyak $5 \mathrm{ml}$ diambil dan ditambahkan 5 ml TBA selanjutnya dipanaskan selama 35 menit dalam air mendidih, dinginkan dan diukur absorbansi dengan panjang gelombang $528 \mathrm{~nm}$ dengan larutan blanko sebagai titik nol. Pengujian yang dilakukan mengambil metode dari Leick, et al., (2010) dengan modifikasi.

\section{TVB-N}

Analisa TVB-N menggunakan metode dari Liu, et al., (2019) dengan modifikasi. Sampel sebanyak $20 \mathrm{~g}$ ditimbang, kemudian dihomogenkan dengan TCA 5\% selama 1 menit. Ekstrak disaring menggunakan kertas saring Whatman kemudian ditambahkan $\mathrm{HCl}$ pada hasil filtrasi. Destilat dititrasi dengan $\mathrm{NaOH}$ untuk mengetahui TVB-N.

\section{Analisis Sensoris}

Analisa sensori menggunakan 30 panelis dengan penilaian kesukaan menggunakan skor $1-5$. Atribut yang diujikan adalah warna, tekstur, aroma, dan overall. Pengujian sensori menggunakan metode yang dikemukakan oleh Kim, et al., (2019). Adapun skala untuk masing-masing parameter sensori sebagai beikut: warna= 1: kemerahan, 2: putih pucat kemerahan, 3: putih kemerahan, 4: putih pudar, 5: putih kekuningan. Tekstur $=1$ : lembek, 2: sedikit lembek, 3: agak kenyal, 4: kenyal, 5: sangat kenyal. Aroma $=1$ : sangat busuk, 2: busuk, 3: amis, 4: sedikit amis, 5: tidak amis. Overall $=1$ : sangat tidak suka, 2: tidak suka, 3: netral, 4: suka, 5: sangat suka.

\section{Analisis Statistik}

Penelitian ini menggunakan Rancangan Acak Lengkap Faktorial (RALF) dengan 2 faktor perlakuan. Data yang diperoleh dianalisis dengan SPSS versi 22 menggunakan One Way ANOVA apabila terdapat perbedaan signifikansi antar perlakuan dilanjutkan uji DMRT (Duncan Multiple Range Test) dengan taraf signifikansi sebesar 0,05.

\section{HASIL DAN PEMBAHASAN}

\section{Karakteristik Fisika}

Drip Loss

Drip loss menggambarkan derajat denaturasi dan oksidasi protein (Lyu, et al., 2016). Berdasarkan Tabel 1, diperoleh nilai drip loss pada hari ke-0 dan ke-2.

Tabel 1. Hasil Analisis Drip Loss Daging Ayam

\begin{tabular}{cccc}
\hline \multirow{2}{*}{$\begin{array}{c}\text { Hari } \\
\text { (ke-) }\end{array}$} & $\begin{array}{c}\text { Waktu } \\
\text { Ozonisasi } \\
\text { (Menit) }\end{array}$ & \multicolumn{2}{c}{$\begin{array}{c}\text { Drip Loss Daging Ayam } \\
(\%)\end{array}$} \\
\cline { 3 - 4 } & & \multicolumn{2}{c}{ Suhu Penyimpanan $\left({ }^{\circ} \mathrm{C}\right)$} \\
\hline \multirow{4}{*}{0} & 0 & $2,80^{\mathrm{d}} \pm 0,18$ & $-6,89^{\mathrm{d}} \pm 0,11$ \\
& 5 & $2,36^{\mathrm{c}} \pm 0,24$ & $2,64^{\mathrm{c}} \pm 0,18$ \\
& 10 & $2,10^{\mathrm{b}} \pm 0,11$ & $2,33^{\mathrm{b}} \pm 0,25$ \\
& 15 & $1,89^{\mathrm{a}} \pm 0,13$ & $2,08^{\mathrm{a}} \pm 0,26$ \\
\hline & 0 & $4,23^{\mathrm{d}} \pm 0,33$ & $5,22^{\mathrm{d}} \pm 0,27$ \\
2 & 5 & $3,65^{\mathrm{c}} \pm 0,25$ & $3,88^{\mathrm{c}} \pm 0,26$ \\
& 10 & $3,25^{\mathrm{b}} \pm 0,10$ & $3,56^{\mathrm{b}} \pm 0,04$ \\
& 15 & $3,04^{\mathrm{a}} \pm 0,02$ & $3,19^{\mathrm{a}} \pm 0,13$ \\
\hline
\end{tabular}

Nilai drip loss pada hari ke-0 dan ke2 pada sampel dengan perlakuan ozon 
dapat menghambat kehilangan tetesan pada daging ayam karena dapat mengurangi nilai degradasi protein yang disebabkan oleh mikroba (Lyu, et al., 2016). Namun, suhu beku memiliki pengaruh yang negatif karena dapat memperbesar nilai drip loss karena memberikan kerusakan mekanis (Kaale, et al., 2014). Ketika air dalam bahan membeku, konsentrasi zat terlarut dalam larutan yang tidak membeku meningkat. Hal ini akan menyebabkan denaturasi protein otot serta kerusakan struktur membran yang kemudian akan menyebabkan peningkatan drip loss (Duun, et al., 2008). Semakin lama disimpan menghasilkan nilai drip loss yang semakin besar (Abdalhai, et al., 2014).

Drip loss sering dikaitkan dengan kehilangan nutrisi yang dinyatakan sebagai presentasi dari berat awal produk. Sebagian besar protein yang ditemukan dalam drip adalah protein sarkoplasma yang larut dalam air (Kaale, et al., 2014). Selain itu, denaturasi protein dapat menyebabkan protein pada daging memiliki kemampuan mengikat air yang rendah dan mengakibatkan struktur daging yang terbuka sehingga terjadi peningkatan nilai drip loss (Rini, et al., 2019).

\section{$\underline{\text { Susut Masak }}$}

Tabel 2 menunjukan nilai susut masak dari daging ayam dimana susut masak dengan perlakuan ozon lebih besar dari sampel tanpa perlakuan ozon, hal ini karena susut masak dipengaruhi oleh $\mathrm{pH}$. Peningkatan nilai $\mathrm{pH}$ disebabkan karena adanya penguraian oleh mikroba. Dengan perlakuan ozon dapat menekan laju kenaikan mikroba karena memiliki sifat sterilisasi. $\mathrm{pH}$ yang rendah akan menyebabkan susut masak menjadi lebih tinggi (Risnajati, 2010). pH dengan kisaran 5,1 - 6,1 akan menyebabkan terbukanya struktur daging, sedangkan dengan $\mathrm{pH}$ dengan kisaran 6,2 - 7,2 akan menyebabkan struktur daging yang tertutup namun menjadi lingkungan yang baik untuk perkembangbiakan mikroba (Haq, et al., 2015).

Panas saat pemasakan juga akan mempengaruhi susut masak sampel dimana akan menginduksi miosin dan denaturasi aktin yang akan menyebabkan perubahan struktur myofibrillar, serta migrasi protein sarkoplasma dari serat otot ke arah luar (Ángel-Rendón, et al., 2019). Selain itu, pada hari ke-0 dan ke-2 susut masak sampel yang dibekukan menghasilkan susut masak yang tinggi karena terjadi kerusakan struktur pada jaringan air sehingga air terikat maupun air tidak bergerak dalam daging akan keluar bersama air bebas (Hafid, et al., 2017).

Tabel 2. Hasil Analisis Susut Masak Daging Ayam

\begin{tabular}{cccc}
\hline \multirow{2}{*}{$\begin{array}{c}\text { Hari } \\
\text { (ke-) }\end{array}$} & Waktu Ozonisasi (Menit) & \multicolumn{2}{c}{ Susut Masak Daging Ayam $(\%)$} \\
\cline { 2 - 4 } & & \multicolumn{2}{c}{ Suhu Penyimpanan $\left({ }^{\circ} \mathrm{C}\right)$} \\
\cline { 2 - 4 } & 0 & $20,12^{\mathrm{a}} \pm 0,23$ & -6 \\
\hline & 5 & $21,11^{\mathrm{b}} \pm 0,27$ & $20,79^{\mathrm{a}} \pm 0,18$ \\
& 10 & $21,71^{\mathrm{c}} \pm 0,47$ & $21,94^{\mathrm{b}} \pm 0,59$ \\
& 15 & $24,15^{\mathrm{d}} \pm 0,33$ & $24,22^{\mathrm{c}} \pm 0,40$ \\
& 0 & $22,42^{\mathrm{a}} \pm 0,43$ & $26,87^{\mathrm{d}} \pm 0,06$ \\
\hline & 5 & $28,57^{\mathrm{b}} \pm 0,84$ & $27,14^{\mathrm{a}} \pm 0,36$ \\
& 10 & $30,28^{\mathrm{c}} \pm 0,32$ & $29,91^{\mathrm{b}} \pm 0,31$ \\
& 15 & $31,58^{\mathrm{d}} \pm 0,30$ & $35,03^{\mathrm{c}} \pm 0,14$ \\
& & & $35,50^{\mathrm{d}} \pm 0,35$ \\
\hline
\end{tabular}




\section{Warna}

Pada Tabel 3, nilai kecerahan ( $\left.\mathrm{L}^{*}\right)$, kemerahan $\left(a^{*}\right)$, dan kekuningan $\left(b^{*}\right)$ mengalami peningkatan dari hari ke-0 menuju hari ke-2 untuk sampel yang disimpan pada suhu $10^{\circ} \mathrm{C}$, sedangkan sampel yang disimpan pada suhu $-6^{\circ} \mathrm{C}$ mengalami penurunan. Sampel dengan perlakuan ozon tidak lebih baik pada atribut warna daripada sampel tanpa perlakuan karena sterilisasi menggunakan ozon pada daging akan menyebabkan ikatan ganda konjugasi dari ruptur mioglobin, sehingga menyebabkan oksidasi dan juga pecahnya kromofor dan kemudian menyebabkan perubahan warna pada daging (Lyu, et al., 2016). Oksidasi lipid dan oksidasi pada daging akan mempengaruhi nilai dari kemerahan $\left(a^{*}\right)$ dan kekuningan $\left(b^{*}\right)$ dimana oksidasi pigmen dapat mengoksidasi atom besi atau denaturasi molekul mioglobin secara negatif mengubah warna produk (Selani, et al., 2011). Selain itu, penyimpanan beku akan mengakibatkan perubahan warna pada dada ayam, karena gangguan sel parsial dan migrasi darah yang timbul dari pembekuan lambat daging (Freitas, et al., 2015). Pembekuan akan menyebabkan warna daging menjadi lebih gelap daripada daging yang tidak dibekukan. Pembentukan kristal es pada daging selama pembekuan menyebabkan serangkaian perubahan yang mempengaruhi kualitas daging terutama warnanya (Aroeira, et al., 2017).

Tabel 3. Hasil Analisis Warna Daging Ayam

\begin{tabular}{cccccccc}
\hline \multirow{2}{*}{$\begin{array}{c}\text { Hari } \\
(\text { ke- })\end{array}$} & $\begin{array}{c}\text { Waktu } \\
\text { Ozonisasi } \\
\text { (Menit) }\end{array}$ & \multicolumn{2}{c}{ Kecerahan Daging Ayam $\left(\mathrm{L}^{*}\right)$} & \multicolumn{2}{c}{$\begin{array}{c}\text { Kemerahan }\left(\mathrm{a}^{*}\right) \text { Daging } \\
\text { Ayam }\end{array}$} & \multicolumn{2}{c}{$\begin{array}{c}\text { Kekuningan }\left(\mathrm{b}^{*}\right) \text { Daging } \\
\text { Ayam }\end{array}$} \\
\cline { 2 - 8 } & & \multicolumn{2}{c}{ Suhu Penyimpanan $\left({ }^{\circ} \mathrm{C}\right)$} & \multicolumn{2}{c}{ Suhu Penyimpanan $\left({ }^{\circ} \mathrm{C}\right)$} & Suhu Penyimpanan $\left({ }^{\circ} \mathrm{C}\right)$ \\
\hline & 0 & $51,73^{\mathrm{c}} \pm 0,83$ & $51,08^{\mathrm{c}} \pm 0,01$ & $2,65^{\mathrm{c}} \pm 0,22$ & $4,94^{\mathrm{c}} \pm 0,16$ & $3,25^{\mathrm{a}} \pm 0,12$ & $5,73^{\mathrm{a}} \pm 0,24$ \\
& 5 & $45,42^{\mathrm{a}} \pm 0,64$ & $49,53^{\mathrm{a}} \pm 0,46$ & $2,54^{\mathrm{d}} \pm 0,38$ & $8,67^{\mathrm{d}} \pm 0,05$ & $6,84^{\mathrm{c}} \pm 1,27$ & $9,73^{\mathrm{c}} \pm 0,59$ \\
0 & 10 & $48,44^{\mathrm{b}} \pm 0,17$ & $50,20^{\mathrm{b}} \pm 0,06$ & $3,81^{\mathrm{a}} \pm 0,34$ & $0,44^{\mathrm{a}} \pm 0,02$ & $7,05^{\mathrm{b}} \pm 0,50$ & $6,29^{\mathrm{b}} \pm 0,07$ \\
& 15 & $53,71^{\mathrm{d}} \pm 1,72$ & $52,83^{\mathrm{d}} \pm 0,75$ & $3,58^{\mathrm{b}} \pm 0,19$ & $3,35^{\mathrm{b}} \pm 0,16$ & $8,69^{\mathrm{c}} \pm 1,16$ & $6,60^{\mathrm{c}} \pm 0,10$ \\
\hline & 0 & $52,79^{\mathrm{b}} \pm 0,87$ & $47,41^{\mathrm{b}} \pm 0,50$ & $2,74^{\mathrm{a}} \pm 0,24$ & $2,55^{\mathrm{a}} \pm 0,11$ & $9,95^{\mathrm{a}} \pm 0,27$ & $4,32^{\mathrm{a}} \pm 0,17$ \\
& 5 & $48,89^{\mathrm{a}} \pm 0,86$ & $49,16^{\mathrm{a}} \pm 0,62$ & $3,86^{\mathrm{b}} \pm 0,31$ & $3,34^{\mathrm{b}} \pm 0,10$ & $9,34^{\mathrm{b}} \pm 0,36$ & $7,94^{\mathrm{b}} \pm 0,05$ \\
& 10 & $49,67^{\mathrm{b}} \pm 0,46$ & $49,67^{\mathrm{b}} \pm 0,05$ & $3,32^{\mathrm{c}} \pm 0,23$ & $3,32^{\mathrm{c}} \pm 0,23$ & $8,67^{\mathrm{b}} \pm 0,09$ & $8,67^{\mathrm{b}} \pm 0,09$ \\
& 15 & $57,79^{\mathrm{c}} \pm 0,34$ & $49,10^{\mathrm{c}} \pm 0,28$ & $3,33^{\mathrm{a}} \pm 0,46$ & $1,92^{\mathrm{a}} \pm 0,00$ & $8,71^{\mathrm{a}} \pm 0,42$ & $5,49^{\mathrm{a}} \pm 0,01$ \\
\hline
\end{tabular}

\section{Karakteristik Kimia}

Aktivitas Air

Dari aktivitas air pada Tabel 4 , dapat diketahui bahwa terjadi penurunan $a_{w}$ pada hari ke-2 hal ini diakibatkan aktivitas air merupakan air bebas dimana air bebas mudah mengalami penguapan dibandingkan dengan air terikat dalam daging (Yuanita, et al., 2009). Jumlah air yang dilepas dipengaruhi oleh lama pembekuan, suhu pembekuan, dan suhu pencairan. Ini mempengaruhi penurunan WHC karena berkurangnya sifat hidrofilitas sehingga menurunkan kemampuan mengikat air (Nento \& Ibrahim, 2017).
Selain itu, kontaminasi mikroba dapat menyebabkan protein bahan terdegradasi, semakin banyak protein terdegradasi maka akan menurunkan kemampuan dalam mengikat air (WHC) dan akan menaikkan nilai $a_{w}$ (Arief, et al., 2012). Dengan perlakuan ozon dapat menjaga nilai $a_{w}$ dikarenakan ozon merupakan salah satu bahan desinfeksi yang dapat membunuh mikroba (Saraslifah, et al., 2016). Dilaporkan ozon mampu mengeliminasi patogen bawaan seperti Salmonella, Listeria monocytogenes, dan Staphylococcus (Muhlisin, et al., 2015). 
Tabel 4. Hasil Analisis $a_{w}$ pada Daging Ayam

\begin{tabular}{cccc}
\hline \multirow{2}{*}{$\begin{array}{c}\text { Hari } \\
\text { (ke-) }\end{array}$} & $\begin{array}{c}\text { Waktu } \\
\text { Ozonisasi } \\
\text { (Menit) })\end{array}$ & \multicolumn{2}{c}{$\begin{array}{c}\text { Aktivitas Air }\left(a_{w}\right) \text { Daging } \\
\text { Ayam }\end{array}$} \\
\cline { 3 - 4 } & & \multicolumn{2}{c}{ Suhu Penyimpanan $\left({ }^{\circ} \mathrm{C}\right)$} \\
\hline & 0 & $0,93^{\mathrm{a}} \pm 0,01$ & $0,93^{\mathrm{a}} \pm 0,00$ \\
0 & 5 & $0,95^{\mathrm{b}} \pm 0,01$ & $0,95^{\mathrm{b}} \pm 0,06$ \\
& 10 & $0,93^{\mathrm{a}} \pm 0,01$ & $0,93^{\mathrm{a}} \pm 0,01$ \\
& 15 & $0,95^{\mathrm{b}} \pm 0,01$ & $0,95^{\mathrm{b}} \pm 0,01$ \\
\hline & 0 & $0,91^{\mathrm{b}} \pm 0,00$ & $0,92^{\mathrm{b}} \pm 0,01$ \\
2 & 5 & $0,91^{\mathrm{ab}} \pm 0,01$ & $0,92^{\mathrm{ab}} \pm 0,01$ \\
& 10 & $0,90^{\mathrm{a}} \pm 0,00$ & $0,91^{\mathrm{a}} \pm 0,01$ \\
& 15 & $0,90^{\mathrm{a}} \pm 0,00$ & $0,91^{\mathrm{a}} \pm 0,01$ \\
\hline
\end{tabular}

$\underline{\mathrm{pH}}$

Berdasarkan Tabel 5, dapat diketahui bahwa nilai $\mathrm{pH}$ dari hari ke-0 menuju hari ke-2 mengalami peningkatan dimana peningkatan ini selaras dengan kerusakan produk yang ditandai dengan meningkatnya aktivitas mikroorganisme selama penyimpanan hal ini terjadi pada produk daging yang dilakukan proses pengasapan (Jahidin, 2016). Selama penyimpanan daging segar terjadi proses autolisis dan penyerangan bakteri. Proses biokimia diantaranya adalah terjadi penguraian oleh bakteri dan hasil metabolisme akan mempercepat proses pembusukan (Nofreeana, et al., 2017). Peningkatan ini diakibatkan karena protein pada daging ayam mengalami pemecahan menjadi senyawa volatil seperti amonia.

Tabel 5. Hasil Analisis $\mathrm{pH}$ pada Daging Ayam

\begin{tabular}{cccc}
\hline \multirow{2}{*}{$\begin{array}{c}\text { Hari } \\
(\text { ke- })\end{array}$} & $\begin{array}{c}\text { Waktu } \\
\text { Ozonisasi } \\
\text { (Menit) }\end{array}$ & \multicolumn{2}{c}{ pH Daging Ayam } \\
\cline { 3 - 4 } & \multicolumn{2}{c}{ Suhu Penyimpanan $\left({ }^{\circ} \mathrm{C}\right)$} \\
\hline \multirow{4}{*}{0} & 0 & $5,93^{\mathrm{c}} \pm 0,04$ & $5,93^{\mathrm{c}} \pm 0,05$ \\
& 5 & $5,81^{\mathrm{b}} \pm 0,04$ & $5,75^{\mathrm{b}} \pm 0,04$ \\
& 10 & $5,74^{\mathrm{a}} \pm 0,06$ & $5,66^{\mathrm{a}} \pm 0,04$ \\
& 15 & $5,73^{\mathrm{a}} \pm 0,02$ & $5,66^{\mathrm{a}} \pm 0,04$ \\
\hline & 0 & $6,89^{\mathrm{c}} \pm 0,03$ & $6,29^{\mathrm{c}} \pm 0,03$ \\
2 & 5 & $6,27^{\mathrm{b}} \pm 0,05$ & $5,98^{\mathrm{b}} \pm 0,12$ \\
& 10 & $5,92^{\mathrm{a}} \pm 0,03$ & $5,81^{\mathrm{a}} \pm 0,08$ \\
& 15 & $5,88^{\mathrm{a}} \pm 0,01$ & $5,76^{\mathrm{a}} \pm 0,04$ \\
\hline
\end{tabular}

Senyawa amonia akan berinteraksi dengan air yang terkandung pada daging ayam kemudian membentuk ammonium hidroksida, dimana senyawa ini bersifat basa (Amin, 2012). Laju kenaikan nilai $\mathrm{pH}$ dapat ditekan dengan penggunaan ozon karena merupakan properti antimikroba, hal ini ditunjukan $\mathrm{pH}$ awal hari ke-0 berkisar 6.80 menjadi $\mathrm{pH} 7.12$ pada hari ke-16 (Gertzou, et al., 2017) sehingga pada sampel yang mendapatkan perlakuan ozon memiliki nilai $\mathrm{pH}$ yang lebih rendah. Selain itu, pengaruh dari suhu dingin dapat menurunkan energi kinestetik semua molekul dalam sistem sehingga dapat menurunkan kecepatan reaksi kimia (Jaelani, et al., 2014).

\section{TBARS}

Hasil TBARS pada daging ayam hari ke-0 dan ke-2 dapat dilihat pada Tabel 6, dimana nilai TBARS pada hari ke-0 mayoritas mengalami peningkatan pada hari ke-2. Uji TBARS ini mengukur produk MDA, keton, dan oksidasi. Nilai TBARS yang diperoleh mewakili tingkat oksidasi lipid (Kim, et al., 2020).

Tabel 6. Hasil Analisis TBARS pada Daging Ayam

\begin{tabular}{|c|c|c|c|}
\hline \multirow{3}{*}{$\begin{array}{l}\text { Hari } \\
\text { (ke-) }\end{array}$} & \multirow{3}{*}{$\begin{array}{l}\text { Waktu } \\
\text { Ozonisasi } \\
\text { (Menit) }\end{array}$} & \multicolumn{2}{|c|}{$\begin{array}{l}\text { TBARS Daging Ayam } \\
(\mathrm{ppm})\end{array}$} \\
\hline & & \multicolumn{2}{|c|}{ Suhu Penyimpanan $\left({ }^{\circ} \mathrm{C}\right)$} \\
\hline & & 10 & -6 \\
\hline \multirow{4}{*}{0} & 0 & $0,17^{\mathrm{a}} \pm 0,01$ & $0,17^{\mathrm{a}} \pm 0,01$ \\
\hline & 5 & $0,24^{\mathrm{b}} \pm 0,01$ & $0,27^{\mathrm{b}} \pm 0,01$ \\
\hline & 10 & $0,30^{\mathrm{c}} \pm 0,01$ & $0,28^{\mathrm{c}} \pm 0,01$ \\
\hline & 15 & $0,34^{\mathrm{d}} \pm 0,01$ & $0,27^{\mathrm{d}} \pm 0,01$ \\
\hline \multirow{4}{*}{2} & 0 & $0,54^{\mathrm{c}} \pm 0,01$ & $0,26^{\mathrm{c}} \pm 0,03$ \\
\hline & 5 & $0,27^{\mathrm{a}} \pm 0,01$ & $0,24^{\mathrm{a}} \pm 0,01$ \\
\hline & 10 & $0,48^{\mathrm{b}} \pm 0,01$ & $0,26^{\mathrm{b}} \pm 0,01$ \\
\hline & 15 & $0,31^{\mathrm{b}} \pm 0,01$ & $0,44^{\mathrm{b}} \pm 0,01$ \\
\hline
\end{tabular}

Sampel dengan perlakuan ozon memiliki nilai yang lebih tinggi daripada sampel kontrol dan semakin tinggi pula apabila sampel semakin lama direndam karena sifat pengoksidasi ozon akan mempromosikan terjadinya oksidasi asam lemak tak jenuh dalam daging. Namun pada beberapa hari selanjutnya akan mengubah nilai TBARS menjadi lebih rendah (Lyu, et al., 2016). Pada hari ke-0 
maupun ke-2, sampel dengan penyimpanan suhu $-6^{\circ} \mathrm{C}$ memiliki nilai TBARS yang lebih rendah, oksidasi lemak masih dapat berlangsung pada suhu sangat rendah yaitu $-18^{\circ} \mathrm{C}$.

Penyimpanan beku dapat menekan tingginya laju oksidasi tetapi tidak dapat menghentikan jumlah lemak yang teroksidasi. Nilai TBARS cenderung meningkat, tetapi tidak teruapkan selama pembekuan dan terakumulasi pada bahan selama penyimpanan beku sehingga tidak menimbulkan bau yang tengik (Utami, et al., 2015). Konsentrasi lebih tinggi dari 0,5 $\mathrm{mg} / \mathrm{kg}$ merupakan nilai ambang batas untuk presepsi tengik oleh konsumen (Shon, et al., 2010). Sehingga, pada hari ke-2 sampel penyimpanan suhu $10^{\circ} \mathrm{C}$ dengan perendaman 0 menit telah tercium aroma tengik dari sampel.

\section{TVB-N}

Hasil uji TVB-N dapat dilihat pada Tabel 7, bahwa nilai TVB-N pada hari ke-0 sampel yang direndam menggunakan larutan ozon menghasilkan nilai yang semakin rendah seiring lama perendaman. Namun, pada hari ke-2 hampir semua sampel mengalami peningkatan nilai TVB$\mathrm{N}$ meskipun sampel dengan ozon tetap lebih rendah dari sampel kontrol untuk masing-masing suhu penyimpanan. Analisa Total Volatile Base Nitrogen (TVB-N) dilakukan untuk mengetahui tingkat kebusukan berdasarkan akumulasi senyawa-senyawa basa seperti amoniak, trimetilamin, dan senyawa volatil lainnya yang menguap (Sholahuddin, 2020). Peningkatan nilai TVB-N dikarenakan degradasi protein, sehingga dapat disimpulkan semakin tinggi nilai TVB-N maka nilai degradasi protein pada sampel semakin besar (Kawiji, et al., 2014).

Tabel 7. Hasil Analisis TVB-N pada Daging Ayam

\begin{tabular}{|c|c|c|}
\hline \multirow{3}{*}{$\begin{array}{l}\text { Hari } \\
(\mathrm{ke}-)\end{array}$} & \multirow{3}{*}{$\begin{array}{c}\text { Waktu } \\
\text { Ozonisasi } \\
\text { (Menit) }\end{array}$} & $\begin{array}{c}\text { TVB-N Daging Ayam } \\
\text { (mg N/100 gr) }\end{array}$ \\
\hline & & Suhu Penyimpanan $\left({ }^{\circ} \mathrm{C}\right)$ \\
\hline & & 10 \\
\hline
\end{tabular}

\begin{tabular}{cccc}
\hline & 0 & $14,98^{\mathrm{d}} \pm 0,02$ & $14,98^{\mathrm{d}} \pm 0,02$ \\
& 5 & $13,44^{\mathrm{c}} \pm 0,13$ & $13,19^{\mathrm{c}} \pm 0,10$ \\
0 & 10 & $8,31^{\mathrm{b}} \pm 0,06$ & $9,14^{\mathrm{b}} \pm 0,30$ \\
& 15 & $8,52^{\mathrm{a}} \pm 0,05$ & $8,34^{\mathrm{a}} \pm 0,02$ \\
\hline & 0 & $42,42^{\mathrm{d}} \pm 0,24$ & $23,74^{\mathrm{d}} \pm 0,21$ \\
& 5 & $37,63^{\mathrm{c}} \pm 0,05$ & $13,76^{\mathrm{c}} \pm 0,09$ \\
2 & 10 & $22,32^{\mathrm{a}} \pm 0,16$ & $9,12^{\mathrm{a}} \pm 0,02$ \\
& 15 & $25,57^{\mathrm{b}} \pm 0,02$ & $8,06^{\mathrm{b}} \pm 0,04$ \\
\hline
\end{tabular}

Kerusakan protein disebabkan karena pecahnya protein hasil aktivitas mikroba dan enzim autolitik dan proteolitik. Selain itu, peningkatan nilai TVB-N dipengaruhi oleh produksi basa volatil seperti $\mathrm{NH}_{3}$, TMA, DMA, dan hiposantin dan juga dapat dipengaruhi oleh senyawa non-volatil seperti histamin (Amin, 2012). Sampel dengan perlakuan ozon mampu mempertahankan laju kenaikan nilai TVB$\mathrm{N}$ karena ozon memiliki sifat sterilisasi yang kuat sehingga mampu mengurangi pertumbuhan mikroorganisme aerob dalam daging (Lyu, et al., 2016). Sampel dengan penyimpanan $-6^{\circ} \mathrm{C}$ pada hari ke-2 tidak mengalami peningkatan yang tinggi untuk lama perendaman 5 menit namun pada sampel kontrol mengalami peningkatan yang tinggi walaupun tidak setinggi sampel kontrol dengan penyimpanan $10^{\circ} \mathrm{C}$. Pada suhu rendah reproduksi bakteri akan terhambat (Wang, et al., 2020). Selain itu, proses penguraian basa volatil oleh bakteri juga akan terhambat pada suhu rendah (Barokah, et al., 2018).

\section{Karakteristik Sensoris}

Warna

Hasil yang didapat pada Tabel 8 adalah sampel dengan perlakuan ozon menunjukkan atribut yang lebih baik dari sampel kontrol. Atribut warna merupakan daya tarik yang utama untuk konsumen dalam menilai barang atau suatu produk. Warna merupakan atribut yang pertama kali disadari oleh konsumen sebelum mengenal dan menilai atribut atau sifat lainnya dalam produk (Marlina, et al., 2012). Pada hari ke-0 nilai warna tertinggi berada pada sampel dengan perendaman 15 menit dan waktu penyimpanan $-6^{\circ} \mathrm{C}$. 
Tabel 8. Hasil Analisis Warna Daging Ayam

\begin{tabular}{cccc}
\hline \multirow{2}{*}{$\begin{array}{c}\text { Hari } \\
\text { (ke-) }\end{array}$} & $\begin{array}{c}\text { Waktu } \\
\text { Ozonisasi } \\
\text { (Menit) }\end{array}$ & \multicolumn{2}{c}{$\begin{array}{c}\text { Atribut Warna } \\
\text { Daging Ayam }\end{array}$} \\
\cline { 3 - 4 } & & \multicolumn{2}{c}{ Suhu Penyimpanan $\left({ }^{\circ} \mathrm{C}\right)$} \\
\hline & 0 & $3,06^{\mathrm{a}} \pm 0,82$ & -6 \\
\hline & 5 & $3,26^{\mathrm{a}} \pm 0,82$ & $3,23^{\mathrm{a}} \pm 0,77$ \\
0 & 10 & $3,46^{\mathrm{b}} \pm 0,72$ & $3,93^{\mathrm{b}} \pm 0,86$ \\
& 15 & $3,46^{\mathrm{c}} \pm 0,81$ & $4,60^{\mathrm{c}} \pm 0,49$ \\
\hline & 0 & $2,56^{\mathrm{a}} \pm 0,50$ & $2,86^{\mathrm{a}} \pm 0,57$ \\
& 5 & $3,13^{\mathrm{b}} \pm 0,68$ & $3,23^{\mathrm{b}} \pm 0,67$ \\
2 & 10 & $3,36^{\mathrm{c}} \pm 0,49$ & $3,63^{\mathrm{c}} \pm 0,76$ \\
& 15 & $3,40^{\mathrm{c}} \pm 0,67$ & $3,80^{\mathrm{c}} \pm 0,71$ \\
\hline
\end{tabular}

Daging ayam segar memiliki warna putih kekuningan yang disebabkan oleh provitamin A yang terletak pada lemak daging dan pigmen oksimioglobin. Pigmen ini merupakan pigmen penting pada daging ayam segar yang hanya terdapat pada permukaan daging saja dan menggambarkan warna daging yang diinginkan konsumen (Saskiawan, et al., 2017). Pada hari ke-2 semua sampel mengalami penurunan kesukaan pada atribut warna oleh panelis.

Perubahan warna daging ini dipicu oleh oksidasi senyawa $\mathrm{Fe}^{2+}$ pada oksimioglobin menjadi $\mathrm{Fe}^{3+}$ (Saskiawan, et al., 2017). Selain itu, perubahan warna gelap disebabkan karena pengeluaran darah yang tidak sempurna disebabkan oleh pigmen haemoglobin (Afrianti, et al., 2013). Hasil percobaan yang dilakukan oleh Lyu, et al., (2016) menghasilkan sampel yang diberi perlakuan $\mathrm{O}_{3}$ dan $\mathrm{CO}$ memberikan nilai kenampakan yang lebih baik pada daging sapi. Ini membuktikan adanya peranan $\mathrm{O}_{3}$ dan $\mathrm{CO}$ dalam menjaga warna daging.

\section{$\underline{\text { Tekstur }}$}

Tekstur merupakan atribut penting pada penilaian ayam karena meruapakan salah satu sifat yang erat kaitannya dengan penerimaan konsumen. Tekstur pada daging berkaitan dengan sifat dari keempukan daging itu sendiri (Saskiawan, et al., 2017). Berdasarkan Tabel 9, dapat dilihat bahwa pada hari ke-0 sampel dengan perlakuan ozon cenderung disukai oleh panelis. Semakin lama sampel kontak dengan ozon maka menghasilkan tekstur yang disukai panelis. Sampel yang paling disukai adalah perendaman 15 menit dan penyimpanan $-6^{\circ} \mathrm{C}$. Namun, semua sampel mengalami penurunan kesukaan pada hari ke-2.

Tabel 9. Hasil Analisis Tekstur Daging Ayam

\begin{tabular}{|c|c|c|c|}
\hline \multirow{3}{*}{$\begin{array}{l}\text { Hari } \\
\text { (ke-) }\end{array}$} & \multirow{3}{*}{$\begin{array}{c}\text { Waktu } \\
\text { Ozonisasi } \\
\text { (Menit) }\end{array}$} & \multicolumn{2}{|c|}{$\begin{array}{c}\text { Atribut Tekstur } \\
\text { Daging Ayam }\end{array}$} \\
\hline & & \multicolumn{2}{|c|}{ Suhu Penyimpanan $\left({ }^{\circ} \mathrm{C}\right)$} \\
\hline & & 10 & -6 \\
\hline \multirow{4}{*}{0} & 0 & $3,00^{\mathrm{a}} \pm 0,58$ & $3,26^{\mathrm{a}} \pm 0,69$ \\
\hline & 5 & $3,36^{\mathrm{b}} \pm 0,96$ & $3,56^{\mathrm{b}} \pm 0,72$ \\
\hline & 10 & $3,53^{b c} \pm 0,57$ & $3,80^{\mathrm{bc}} \pm 0,76$ \\
\hline & 15 & $3,60^{c} \pm 0,96$ & $4,23^{c} \pm 0,67$ \\
\hline \multirow{4}{*}{2} & 0 & $2,20^{\mathrm{a}} \pm 0,96$ & $2,70^{\mathrm{a}} \pm 0,59$ \\
\hline & 5 & $2,86^{\mathrm{b}} \pm 0,68$ & $2,90^{\mathrm{b}} \pm 0,71$ \\
\hline & 10 & $3,30^{\mathrm{c}} \pm 0,70$ & $3,60^{c} \pm 0,72$ \\
\hline & 15 & $3,36^{\mathrm{c}} \pm 0,49$ & $3,70^{c} \pm 0,70$ \\
\hline
\end{tabular}

Nilai kesukaan terhadap tekstur cenderung menurun seiring dengan semakin lama penyimpanan daging (Saskiawan, et al., 2017). Penurunan ini memiliki korelasi dengan nilai $\mathrm{pH}$ daging ayam dimana $\mathrm{pH}$ akan meningkat selama penyimpanan yang menyebabkan daging memiliki permukaan kering dan berwarna gelap sehingga menurunkan kesukaan konsumen (Saskiawan, et al., 2017). Selain itu, penurunan tekstur dipengaruhi oleh drip loss (Tabel 1). Hilangnya cairan dari dalam daging akan memperburuk tekstur daging (Chmiel, et al., 2018). Perlakuan ozon dapat membunuh mikroba pada daging, selain itu perlakuan penyimpanan pada suhu beku mampu menghambat perkembangbiakan dan metabolisme mikroba. Bakteri yang tumbuh pada daging ayam menjadi pemicu perubahan tekstur daging ayam karena akan menggunakan protein, karbohidrat, lemak, dan komponen lain untuk menunjang kehidupannya (Saskiawan, et al., 2017).

\section{Aroma}

Kerusakan daging ayam secara organoleptik dapat ditandai dengan adanya 
bau yang menyimpang (Saskiawan, et al., 2017). Berdasarkan Tabel 10, tingkat kesukaan panelis menurun pada hari ke-2 dimana beberapa sampel telah mengeluarkan bau yang menyimpang.

Tabel 10. Hasil Analisis Aroma Daging Ayam

\begin{tabular}{cccc}
\hline \multirow{2}{*}{$\begin{array}{c}\text { Hari } \\
\text { (ke-) }\end{array}$} & $\begin{array}{c}\text { Waktu } \\
\text { Ozonisasi } \\
\text { (Menit) }\end{array}$ & \multicolumn{2}{c}{$\begin{array}{c}\text { Atribut Aroma Daging } \\
\text { Ayam }\end{array}$} \\
\cline { 3 - 4 } & & \multicolumn{2}{c}{ Suhu Penyimpanan $\left({ }^{\circ} \mathrm{C}\right)$} \\
\hline \multirow{4}{*}{0} & 0 & $2,83^{\mathrm{a}} \pm 0,69$ & $3,40^{\mathrm{a}} \pm 0,81$ \\
& 5 & $3,40^{\mathrm{b}} \pm 0,72$ & $3,43^{\mathrm{b}} \pm 0,62$ \\
& 10 & $3,56^{\mathrm{b}} \pm 0,89$ & $3,56^{\mathrm{b}} \pm 0,67$ \\
& 15 & $3,60^{\mathrm{c}} \pm 1,00$ & $4,23^{\mathrm{c}} \pm 0,56$ \\
\hline \multirow{2}{*}{2} & 0 & $1,93^{\mathrm{a}} \pm 0,82$ & $2,33^{\mathrm{a}} \pm 0,60$ \\
& 5 & $2,53^{\mathrm{b}} \pm 0,68$ & $3,33^{\mathrm{b}} \pm 0,91$ \\
& 10 & $2,76^{\mathrm{bc}} \pm 0,62$ & $3,60^{\mathrm{bc}} \pm 0,89$ \\
& 15 & $2,63^{\mathrm{c}} \pm 0,71$ & $3,90^{\mathrm{c}} \pm 0,75$ \\
\hline
\end{tabular}

Bau busuk ini dihasilkan dari gugus amina yang diproduksi sebagai hasil metabolisme mikroba, seiring bertambahnya waktu penyimpanan menghasilkan aroma yang semakin buruk (Lyu, et al., 2016). Sampel dengan perlakuan ozon memiliki nilai yang lebih baik dibandingkan sampel kontrol baik pada hari ke-0 maupun hari ke-2.

Semakin lama kontak dengan ozon dihasilkan nilai yang semakin baik. Selain itu, penggunaan suhu beku efektif dalam mempertahankan aroma daging ayam bersamaan dengan ozon. Nilai tertinggi untuk atribut aroma berada pada sampel dengan perendaman selama 15 menit dan suhu penyimpanan $-6^{\circ} \mathrm{C}$. Hasil penelitian yang dilakukan Cantalejo, et al., (2016), sampel daging ayam beku memiliki skor tertinggi dimana perlakuan pendahuluan dengan ozon lebih dari 0,4 ppm menghasilkan perubahan bau terendah dan mampu menyimpan bau yang dapat diterima panelis sampai 8 bulan penyimpanan beku.

\section{Overall}

Berdasarkan dari penilaian keseluruhan yang dapat dilihat pada Tabel 11, semua sampel mengalami penurunan kesukaan oleh panelis seiring lama waktu penyimpanan. Pada hari ke-0 dan ke-2 sampel dengan perlakuan ozon lebih diminati daripada sampel kontrol pada masing-masing suhu penyimpanan.

Tabel 11. Hasil Analisis Overall Daging Ayam

\begin{tabular}{cccc}
\hline \multirow{2}{*}{$\begin{array}{c}\text { Hari } \\
(\text { ke- })\end{array}$} & $\begin{array}{c}\text { Waktu } \\
\text { Ozonisasi } \\
\text { (Menit) }\end{array}$ & \multicolumn{2}{c}{$\begin{array}{c}\text { Atribut Overall Daging } \\
\text { Ayam }\end{array}$} \\
\cline { 3 - 4 } & & \multicolumn{2}{c}{ Suhu Penyimpanan $\left({ }^{\circ} \mathrm{C}\right)$} \\
\hline & 0 & $2,83^{\mathrm{a}} \pm 0,64$ & $3,36^{\mathrm{a}} \pm 0,66$ \\
0 & 5 & $3,33^{\mathrm{b}} \pm 0,71$ & $3,56^{\mathrm{b}} \pm 0,50$ \\
& 10 & $3,50^{\mathrm{b}} \pm 0,68$ & $3,66^{\mathrm{b}} \pm 0,54$ \\
& 15 & $3,60^{\mathrm{c}} \pm 0,62$ & $4,23^{\mathrm{c}} \pm 0,50$ \\
\hline & 0 & $1,93^{\mathrm{a}} \pm 0,90$ & $2,63^{\mathrm{a}} \pm 0,49$ \\
& 5 & $2,80^{\mathrm{b}} \pm 0,47$ & $2,96^{\mathrm{b}} \pm 0,66$ \\
2 & 10 & $3,00^{\mathrm{c}} \pm 0,45$ & $3,50^{\mathrm{c}} \pm 0,57$ \\
& 15 & $2,93^{\mathrm{c}} \pm 0,45$ & $3,73^{\mathrm{c}} \pm 0,52$ \\
\hline
\end{tabular}

Penurunan ini disebabkan karena daging ayam merupakan bahan pangan mentah yang mudah rusak karena kaya akan nutrisi, memiliki $a_{w}$ yang tinggi dan memiliki nilai $\mathrm{pH}$ yang mendekati netral sehingga merupakan media yang baik untuk pertumbuhan mikroba. Daging ayam sendiri memiliki nilai simpan yang lebih rendah (Parnanto, et al., 2014). Namun perlakuan ozon dapat membantu menjaga kualitas dari ayam karena ozon merupakan senyawa pengoksidasi yang kuat dan dapat digunakan sebagai desinfektan (Jiang, et al., 2019). Kemampuan ozon ini didukung dengan penyimpanan suhu dingin karena akan menurunkan energi kinestetik semua molekul dalam sistem sehingga menurunkan kecepatan reaksi kimia termasuk aktivitas metabolisme sel mikroba (Jaelani, et al., 2014).

Dari penilaian atribut sensoris oleh panelis, terdapat beberapa perbedaan dengan yang diuji secara instrumental ataupun pengujian pada laboratorium. Menurut Lyu, et al., (2016), hal ini disebabkan karena setiap panelis memiliki tingkat ketelitian yang berbeda-beda. Masing-masing panelis memiliki perbedaan dalam kemampuan menggunakan skala sensoris. 


\section{KESIMPULAN DAN SARAN}

\section{Kesimpulan}

Berdasarkan hasil dari penelitian dengan menggunakan teknologi ozonisasi dan variasi suhu penyimpanan dapat disimpulkan bahwa pada pengujian drip loss sampel yang dapat mempertahankan kehilangan cairan yaitu pada sampel dengan perendaman ozon selama 15 menit dan suhu penyimpanan $10^{\circ} \mathrm{C}$ yaitu pada hari ke-0 sebesar $1,89 \%$ dan pada hari ke-2 $3,04 \%$. Aktivitas air didapatkan nilai terendah pada perendaman 10 dan 15 menit dengan suhu penyimpanan $10^{\circ} \mathrm{C}$ pada hari ke-2 yaitu 0,90 . Hasil dari uji TBARS pada hari ke-0 meningkat seiring lama kontak dan perlakuan ozon mampu menekan laju kenaikan TVB-N sehingga pada hari ke-2 nilai TVB-N terendah berada pada sampel perendaman 15 menit dengan penyimpanan $-6^{\circ} \mathrm{C}$ sebesar 8,06 mg N/100 gr. Dari segi sensoris dengan menggunakan atribut pengujian warna, tekstur, aroma, dan overall skor tertinggi yang diberikan panelis yaitu pada sampel dengan perendaman 15 menit dan suhu penyimpanan $-6^{\circ} \mathrm{C}$ baik pada hari ke- 0 maupun ke-2.

\section{Saran}

Perlu diadakan penelitian lebih lanjut mengenai pengujian mikrobiologi untuk mengetahui lebih pasti tentang efektivitas ozon dalam membunuh mikroba.

\section{DAFTAR REFERENSI}

Abdalhai, M. H., Bashari, M., Lagnika, C., He, Q., \& Sun, X. (2014). Effect of Ultrasound Treatment Prior to Vacuum and Modified Atmosphere Packaging on Microbial and Physical Characteristics of Fresh Beef. Journal of Food and Nutrition Research, 2(6), 312-320. https://doi.org/10.12691/jfnr-2-6-8

Afrianti, M., Dwiloka, B., \& Setiani, B. E.
(2013). Perubahan Warna, Profil Protein dan Mutu Organoleptik Daging Ayam Boiler Setelah Direndam Dengan Ekstrak Daun Senduduk. Jurnal Aplikasi Teknologi Pangan, 2(3), 116-120.

Amin, R. A. (2012). Effect of Bio Preservation as a Modern Technology on Quality Aspects and Microbial Safety of Minced Beef. 7(2), 38-49. https://doi.org/10.5829/idosi.gjbb.201 2.7.2.64154

Ángel-Rendón, S. V., Filomena-Ambrosio, A., Cordon-Díaz, S., BenítezSastoque, E. R., \& Sotelo-Díaz, L. I. (2019). Ohmic cooking: Application of a novel technology in pork and influences on water holding capacity, cooking loss and colour. International Journal of Gastronomy and Food Science, 17(November 2018), 100164. https://doi.org/10.1016/j.ijgfs.2019.10 0164

Arief, H., Pramono, Y., \& Bintoro, V. (2012). The Influence of Different Concentration From Edible Activity in Beef Meatball At Shelf Life Period. Animal Agriculture Journal, 1(2), 100-108. http://ejournals1.undip.ac.id/index.php/aaj

Aroeira, C. N., de Almeida Torres Filho, R., Fontes, P. R., de Lemos Souza Ramos, A., de Miranda Gomide, L. A., Ladeira, M. M., \& Ramos, E. M. (2017). Effect of freezing prior to aging on myoglobin redox forms and CIE color of beef from Nellore and Aberdeen Angus cattle. Meat Science, 125, 16-21. https://doi.org/10.1016/j.meatsci.201 6.11 .010

Asgar, A., Musaddad, D., Setyabudi, D. A., 
\& Hasan, Z. H. (2015). Teknologi Ozonisasi Untuk Mempertahankan Kesegaran Cabai Cultivar Kencana Selama Penyimpanan. Jurnal Penelitian Pascapanen Pertanian, 12(1), 20. https://doi.org/10.21082/jpasca.v12n1 $.2015 .20-26$

Asgar, A., Sugiarto, A. T., Sumartini, \& Ariani, D. (2011). Kajian Ozonisasi (O3) Terhadap Karakteristik Kubis Bunga (Brassica oleracea var. botrytis) Segar selama Penyimpanan Suhu Dingin. Berita Biologi, 10(6), 787-795.

https://doi.org/10.1017/CBO9781107 415324.004

Barokah, G. R., Putri, A. K., Anissah, U., \& Murtini, J. T. (2018). Pembentukan Formaldehida Alami dan Penurunan Mutu Ikan Kerapu Cantik ( Epinephelus fuscoguttatus $\times \mathrm{E}$. microdon) selama Penyimpanan pada Suhu Beku. Jurnal Pascapanen Dan Bioteknologi Kelautan Dan Perikanan, $\quad 13(1), \quad 71$. https://doi.org/10.15578/jpbkp.v13i1. 511

Cantalejo, M. J., Zouaghi, F., \& PérezArnedo, I. (2016). Combined effects of ozone and freeze-drying on the shelf-life of Broiler chicken meat. LWT - Food Science and Technology, 68, 400-407. https://doi.org/10.1016/j.lwt.2015.12. 058

Chmiel, M., Hać-Szymańczuk, E., Adamczak, L., Pietrzak, D., Florowski, T., \& Cegiełka, A. (2018). Quality changes of chicken breast meat packaged in a normal and in a modified atmosphere. Journal of Applied Poultry Research, 27(3), 349-362. https://doi.org/10.3382/japr/pfy004
Duun, A. S., Hemmingsen, A. K. T., Haugland, A., \& Rustad, T. (2008). Quality changes during superchilled storage of pork roast. LWT - Food Science and Technology, 41(10), 2136-2143. https://doi.org/10.1016/j.lwt.2008.02. 001

Freitas, E. R., Da Silva Borges, A., Pereira, A. L. F., Abreu, V. K. G., Trevisan, M. T. S., \& Watanabe, P. H. (2015). Effect of dietary ethanol extracts of mango (Mangifera indica L.) on lipid oxidation and the color of chicken meat during frozen storage. Poultry Science, 94(12), 2989-2995. https://doi.org/10.3382/ps/pev295

Gertzou, I. N., Karabagias, I. K., Drosos, P. E., \& Riganakos, K. A. (2017). Effect of combination of ozonation and vacuum packaging on shelf life extension of fresh chicken legs during storage under refrigeration. Journal of Food Engineering, 213, 18-26. https://doi.org/10.1016/j.jfoodeng.20 17.06.026

Gustiani, E. (2009). Pengendalian Cemaran Mikroba pada Bahan Pangan Asal Ternak (Daging dan Susu) Mulai dari Peternakan Sampai Dihidangkan. Jurnal Litbang Pertanian, 28(3), 96100.

http://203.190.37.42/publikasi/p3283 093.pdf

Hafid, H., Napirah, A., \& Meliana, L. (2017). Efek Pencairan Kembali terhadap $p H$, Susut Masak dan Warna Daging Sapi Bali yang Dibekukan. Hafid 2008, 275-279. https://doi.org/10.14334/pros.semnas. tpv-2017-p.276-280

Haq, A.N., Septinova, D., \& Santosa, P.E. (2015). The Physical of Beef from 
Traditional Market in Bandar Lampung. Jurnal Ilmiah Peternakan Terpadu, 3(3), 98-103.

Jaelani, A., Dharmawati, S., \& Wanda. (2014). Berbagai Lama Penyimpanan Daging Ayam Broiler Segar Dalam Kemasan Plastik Pada Lemari Es (Suhu 4oC) Dan Pengaruhnya Terhadap Sifat Fisik Dan Organoleptik. Ziraa'ah Majalah Ilmiah Pertanian, 39(3), 119-128.

Jahidin, J. (2016). Kualitas Fisik Daging Asap Dari Daging Yang Berbeda Pada Pengasapan Tradisional. Jurnal Ilmiah Ilmu-Ilmu Peternakan Universitas Jambi, XIX(1), 27-34. https://doi.org/10.22437/jiiip.v19i1.3 106

Jeong, J. Y., \& Claus, J. R. (2010). Color stability and reversion in carbon monoxide packaged ground beef. Meat Science, 85(3), 525-530. https://doi.org/10.1016/j.meatsci.201 0.02 .027

Jiang, H. J., Cheen, N., Shen, Z. Q., Yin, J., Qiu, Z. G., Miao, J., Yang, Z. W., Shi, D. Y., Wang, H. R., Wang, X. W., LI, J. W., Yang, D., \& Jin, M. (2019). Inactivation of Poliovirus by Ozone and the Impact of Ozone on the Viral Genome. Biomedical and Environmental Sciences, 32(5), 324333.

https://doi.org/10.3967/bes2019.044

Kaale, L. D., Eikevik, T. M., Rustad, T., \& Nordtvedt, T. S. (2014). Changes in water holding capacity and drip loss of Atlantic salmon (Salmo salar) muscle during superchilled storage. LWT - Food Science and Technology, $55(2)$, 528-535. https://doi.org/10.1016/j.lwt.2013.10. 021
Kawiji, K., Utami, R., \& Khasanah, L. U. (2014). Pengaruh Penambahan Oleoresin Daun Jeruk Purut (Citrus Hystrix Dc) Pada Edible Coating Terhadap Penghambatan Kerusakan Oksidatif Dan Mikrobiologis Daging Sapi Yang Disimpan Di Suhu Rendah. Jurnal Teknologi Hasil Pertanian, 7(1), 39-47. https://doi.org/10.20961/jthp.v0i0.12 916

Kim, H. J., Kim, H. J., Jeon, J. J., Nam, K. C., Shim, K. S., Jung, J. H., Kim, K. S., Choi, Y., Kim, S. H., \& Jang, A. (2020). Comparison of the quality characteristics of chicken breast meat from conventional and animal welfare farms under refrigerated storage. Poultry Science, 99(3), 1788-1796.

https://doi.org/10.1016/j.psj.2019.12. 009

Kim, M. A., van Hout, D., Zandstra, E. H., \& Lee, H. S. (2019). Consumer acceptance measurement focusing on a specified sensory attribute of products: Can the attribute-specified degree of satisfaction-difference (DOSD) method replace hedonic scaling? Food Quality and Preference, 75(August 2018), 198208.

https://doi.org/10.1016/j.foodqual.20 19.03.009

Leick, C. M., Puls, C. L., Ellis, M., Killefer, J., Carr, T. R., Scramlin, S. M., England, M. B., Gaines, A. M., Wolter, B. F., Carr, S. N., \& Mckeith, F. K. (2010). Effect of distillers dried grains with solubles and ractopamine (Paylean) on quality and shelf-life of fresh pork and bacon. Journal of Animal Science, 88(8), 2751-2766. https://doi.org/10.2527/jas.2009-2472

Liu, C. xing, Xiao, Y. ping, Hu, D. wen, 
Liu, J. xin, Chen, W., \& Ren, D. xi. (2019). The safety evaluation of chilled pork from online platform in China. Food Control, 96(June 2018), 244-250.

https://doi.org/10.1016/j.foodcont.20 18.09.025

Lyu, F., Shen, K., Ding, Y., \& Ma, X. (2016). Effect of pretreatment with carbon monoxide and ozone on the quality of vacuum packaged beef meats. Meat Science, 117, 137-146. https://doi.org/10.1016/j.meatsci.201 6.02 .036

Marlina, E. T., Balia, R. L., Hidayati, A., \& Pembahasan, H. (2012). Uji Organoleptik Daging Ayam yang Diberi Ransum yang Mengandung Lumpur Susu Terfermentasi oleh Aspergillus niger (Organoleptic. Jurnal Ilmu Ternak, 12(1), 20-23. https://doi.org/10.24198/jit.v12i1.513 2

McDermott, A., Whyte, P., Brunton, N., Lyng, J., Fagan, J., \& Bolton, D. J. (2018). The effect of organic acid and sodium chloride dips on the shelf-life of refrigerated Irish brown crab (Cancer pagurus) meat. Lwt, 98(July), 141-147.

https://doi.org/10.1016/j.lwt.2018.08. 039

Muhlisin, Cho, Y., Choi, J. H., Hahn, T. W., \& Lee, S. K. (2015). Bacterial counts and oxidative properties of chicken breast inoculated with salmonella typhimurium exposed to gaseous ozone. Journal of Food Safety, 35(1), 137-144. https://doi.org/10.1111/jfs.12161

Nento, W. R., \& Ibrahim, P. S. (2017). Quality analysis of tuna fish nugget (Thunnus sp.) during frozen storage. Journal of Agritech Science, 1(2),
$75-81$.

Nofreeana, A., Masi, A., Deviarni, I. M., Studi, P., Pengolahan, T., Perikanan, H., \& Pontianak, P. N. (2017). Effect Of Vacuum Packaging on Microbiology Change, Water Activity and $\mathrm{pH}$ in Smoke Stingray. Jurnal Teknologi Pangan, 8(1), 2597-436.

Novak, J. S., \& Yuan, J. T. C. (2004). The fate of Clostridium perfringens spores exposed to ozone and/or mild heat pretreatment on beef surfaces followed by modified atmosphere packaging. Food Microbiology, 21(6), 667-673. https://doi.org/10.1016/j.fm.2004.03. 003

Parnanto, N. H. R., Atmaka, W., \& Happy, A. (2014). Aplikasi Ekstrak Daun Salam ( syzygium polyanthum ) dan Ayam Broiler Giling selama proses penyimpanan. Jurnal Teknologi Hasil Pertanian, VII(1).

Pratikno, H. (2010). Pengaruh Ekstrak Kunyit (Curcuma Domestica Vahl) Terhadap Bobot Badan Ayam Broiler (Gallus Sp). Buletin Anatomi Dan Fisiologi dh Sellula, 18(2), 39-46. https://doi.org/10.14710/baf.v18i2.26 10

Rini, S. R., Sugiharto, S., \& Mahfudz, L. D. (2019). Pengaruh Perbedaan Suhu Pemeliharaan terhadap Kualitas Fisik Daging Ayam Broiler Periode Finisher. Jurnal Sain Peternakan Indonesia, 14(4), 387-395. https://doi.org/10.31186/jspi.id.14.4.3 87-395

Risnajati, D. (2010). Pengaruh Lama Penyimpanan Dalam Lemari Es Terhadap PH, Daya Ikat Air, Dan Susut Masak Karkas Broiler Yang 
Dikemas Plastik Polyethylen. Jurnal

Ilmu-Ilmu Peternakan, O(0), 309315.

Rusdi, U. D., \& Sulasih, N. (2002). Ozonisation and milk quality. 4(2), 96-107.

Saraslifah, Nur, M., \& Arianto, F. (2016). Pengaruh Ozon yang Dibangkitkan Melalui Reaktor Plasma Berpenghalang Dielektrik Elektroda Silinder Spiral Terhadap Pengawetan Cabai. Youngster Physics Journal, 5(4), 319-326.

Saskiawan, I., Sukarminah, E., Lanti, I., Marta, H., \& Nabila, P. (2017). Pemanfatan Ekstrak Jamur Tiram (Pleurotus spp.) Pada Penyimpanan Daging Ayam Pada Suhu Ruang $\left(26^{\circ} \mathrm{C}\right)$. Jurnal Biologi Indonesia, 13(2), 279-287. http://ejournal.biologi.lipi.go.id/index.php/ju rnal_biologi_indonesia/article/view/3 $402 / 2878$

Selani, M. M., Contreras-Castillo, C. J., Shirahigue, L. D., Gallo, C. R., PlataOviedo, M., \& Montes-Villanueva, N. D. (2011). Wine industry residues extracts as natural antioxidants in raw and cooked chicken meat during frozen storage. Meat Science, 88(3), 397-403.

https://doi.org/10.1016/j.meatsci.201 1.01.017

Shen, M. M., Zhang, L. L., Chen, Y. N., Zhang, Y. Y., Han, H. L., Niu, Y., He, J. T., Zhang, Y. L., Cheng, Y. F., \& Wang, T. (2019). Effects of bamboo leaf extract on growth performance, meat quality, and meat oxidative stability in broiler chickens. Poultry Science, 98(12), 6787-6796. https://doi.org/10.3382/ps/pez404

Sholahuddin, M. (2020). Aplikasi Madu
Sebagai Bahan Halal Pengganti Pengawet Produk Fillet Ikan Pada Masa Transportasi. Halal Product and Research, 3(1), 9-18.

Shon, J., Eo, J. H., \& Eun, J. B. (2010). Effect of soy protein isolate coating on quality attributes of cut raw hanwoo (Korean Cow) beef, aerobically packaged and held refrigerated. Journal of Food Quality, 33 (SUPPL. $1)$, 42-60. https://doi.org/10.1111/j.17454557.2010.00332.x

Situmorang, N. A., Mahfudz, L. D., \& Atmomarsono, U. (2013). Pengaruh Pemberian Tepung Rumput Laut (Gracilaria verrucosa) dalam Ransum Terhadap Efisiensi Penggunaan Protein Ayam Broiler. Animal Agriculture Journal, 2(2), 49-56.

Suradi, K. (2006). Perubahan Sifat Fisik Daging Ayam Broiler Post Mortem Selama Penyimpanan Temperatur Ruang. Jurnal Ilmu Ternak, 6(1), 2327.

Utami, R., Kawiji, Khasanah, L. U., \& Narinda, A. H. (2015). Pengaruh oleoresin daun jeruk purut (Citrus hystrix dc.) pada edible coating terhadap kualitas sosis sapi beku. Jurnal Teknologi Industri Pertanian, 25(2), 116-124.

Wang, Z., He, Z., Zhang, D., Li, H., \& Wang, Z. (2020). Using oxidation kinetic models to predict the quality indices of rabbit meat under different storage temperatures. Meat Science, 162(2), 108042. https://doi.org/10.1016/j.meatsci.201 9.108042

Yuanita, L., Wikandari, P. R., Poedjiastoeti, S., \& Tjahyani, S. (2009). Penggunaan Natrium 
Tripolifosfat untuk Meningkatkan

Masa Simpan Daging Ayam.

Agritech, 29(2), 79-86. 